\title{
RETURNING TO NURSING
}




\section{RETURNING TO NURSING}

\section{A Guide for Nurses and Health Visitors}

Alison Morton-Cooper, RGN

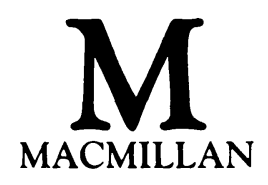


(C) Alison Morton-Cooper 1989

All rights reserved. No reproduction, copy or transmission of this publication may be made without written permission.

No paragraph of this publication may be reproduced, copied or transmitted save with written permission or in accordance with the provisions of the Copyright Act 1956 (as amended), or under the terms of any licence permitting limited copying issued by the Copyright Licensing Agency, 33-4 Alfred Place, London WC1E 7DP.

Any person who does any unauthorised act in relation to this publication may be liable to criminal prosecution and civil claims for damages.

First published 1989

Published by

MACMILLAN EDUCATION LTD

Houndmills, Basingstoke, Hampshire RG21 2XS

and London

Companies and representatives

throughout the world

Typeset by Footnote Graphics, Warminster, Wilts

British Library Cataloguing in Publication Data

Morton-Cooper, Alison

Returning to nursing.

1. Medicine. Nursing - Manuals

I. Title

610.73

ISBN 978-0-333-48076-2

ISBN 978-1-349-10538-0 (eBook)

DOI 10.1007/978-1-349-10538-0 
To Dad, for believing in miracles 


\section{Contents}

Acknowledgements

How to Use This Book

Foreword

viii

ix

$x i$

Introduction

1 Deciding to Return 3

2 Building Professional Confidence 19

3 Practical Issues at Home and Work 37

4 The Back to Nursing Movement and Prospective Employers

5 The NHS and its Mid-life Crisis 81

6 Returning to Learning 101

7 Changes in Nursing Practice 117

$\begin{array}{ll}\text { Postscript } & 133\end{array}$

Appendix 1 The UKCC Code of Professional Conduct for the Nurse, Midwife and Health Visitor 134 Appendix 2 Nursing Journals Available from High Street Newsagents 136 Appendix 3 Careers Information Addresses 138 Index 


\section{Acknowledgements}

I would like to extend my sincere thanks to the many nurses, nurse tutors and health visitors who have assisted me in the preparation of this book by responding to my requests for advice with enthusiasm and generosity.

They include: Marilyn Castle, labour relations officer, Royal College of Nursing; Shirley Goodwin, general secretary of the Health Visitors' Association; Peta Allan, director for professional standards and development at the UK Central Council for Nursing, Midwifery and Health Visiting; Reg Pyne, director for professional conduct at the UKCC; the chief executives of the four National Boards: Lyn Mitchell, David Ravey, J. Walsh and David Jones; Mrs Jean Heath of the ENB Careers Advisory Service; Martin Vousden of Nursing Times.

I owe a great deal to the patience and forbearance of my editorial board, Frances Pickersgill, Philip Burnard, and Tony O'Malley, and to my publisher Mary Waltham for inspired leadership. The book could not have been completed without the assistance of Ann Banfill, or the encouragement of my husband Barrie, and of my son, Alastair, who has learned the secret of playing to the whirr of the typewriter.

AMC, June 1989 


\section{How to Use This Book}

Returning to Nursing is aimed at all qualified nurses and health visitors hoping to return to practice after a career break.

Written with the aspirations and concerns of returners in mind, it provides a re-introduction and update on many of the issues already encountered by experienced nurses, and an introduction to new concepts and developments in line with current recommendations and guidelines on preparation for re-entry.

In the extensive research undertaken for the book it became clear that a number of particular issues posed the greatest challenges to potential returners and to prospective employers. The chapters which follow therefore address these directly. By raising the awareness of returning nurses and health visitors of such important issues as professional accountability, new approaches to the learning process and the learning environment, the implications of research based care and the impact of new technologies in nursing, I hope that the book will help to facilitate a safe and knowledgeable return to practice for both the individual returner and her employer.

The book may be used by individuals or as a companion text to Back to Nursing programmes. Chapters 2 and 7 particularly are intended to provoke discussion and debate, and to provide a basis for independent and group study as seminar or project work before, or in conjunction with, supervised clinical allocations.

Selective annotated bibliographies address clinical and professional topics ranging from individualised care planning to drug administration, safe handling skills, wound management, the nurse's role in cardiopulmonary resuscitation and many other more specialised skills.

The book is very much a general introduction, aimed at providing nurses of all specialties with the essential practical background information required to negotiate a successful return to practice. 
Popular nursing mythologies are demystified and explained and advice given on tailoring re-entry preparation to suit individual learning needs. By concentrating on the practical implications of new ideas this book should help to promote positive strategies for welcoming nurses and health visitors back to practice at a time when their skills are needed and sought after as never before in the profession's long and distinguished history. 


\section{Foreword}

Tomorrow, today will be the 'good old days'. It is easy to make lasting judgements based on impressions and recollections from a time when things were different. It is a fact of our lives that change is constant and that change is often feared. It is also very easy to lose touch. Following a break in nursing practice there may be an understandable hesitation and anxiety about returning because of the inevitable changes that will have taken place. There is also an anxiety that through losing touch with developments, skills are also lost. Circumstances such as these can lead to real apprehension about returning to practice.

This book is a practical and timely guide to the journey leading to that return. It chronicles recent changes within the professions and the health services and is a useful source of reference and information. It is written in a reassuring way that should positively assist nurses, midwives and health visitors and allay understandable anxieties.

The context in which care is given is also subject to change as, indeed, are the professions themselves. Organisational arrangements, educational systems and approaches to treatment and care are all in a continuing state of change and development. For the professions to be sensitive to change, and to meet the needs of patients and clients there must be a constant readiness to develop and adjust to accommodate new challenges. Changes in practice, in turn, call for changes in education and in the professions to ensure that the needs of society are met effectively and that standards are safeguarded for our patients and clients.

The professions, collectively, must face these challenges. Individuals returning to practice also face a personal challenge and have their own needs for support and encouragement so that their important transition from a break to return to practice is assisted. This book should assist this process and help practitioners focus on what personal qualities and skills they bring and not just those areas in which help and information 
may be required. The personal and life experiences which all practitioners bring to practice can enrich nursing, midwifery and health visiting teams and, in turn, the care they give.

I hope that this book will be a major source of practical advice and assistance and will encourage the return of practitioners.

Colin Ralph

Registrar and Chief Executive

United Kingdom Central Council for Nursing, Midwifery and Health Visiting 